\title{
BRUCELLA SPP. ISOLATION FROM DOGS FROM COMMERCIAL BREEDING KENNELS IN SÃO PAULO STATE, BRAZIL
}

\author{
Lara B. Keid $^{1 *}$; Rodrigo M. Soares ${ }^{1}$; Zenaide M. Morais ${ }^{1}$; Leonardo J. Richtzenhain ${ }^{1}$; Sílvio A.Vasconcellos ${ }^{1}$ \\ ${ }^{1}$ Departamento de Medicina Veterinária Preventiva e Saúde Animal, Faculdade de Medicina Veterinária e Zootecnia, \\ Universidade de São Paulo, São Paulo, SP, Brasil. \\ Submitted: July 22, 2003; Approved: May 20, 2004.
}

\begin{abstract}
Dogs from 12 commercial breeding kennels were submitted to clinical investigation and laboratorial tests for diagnosis of Brucella spp. infection. The sampling was carried out between April 2000 and February 2002 and the laboratorial tests employed were agar gel immunediffusion test (AGID) and blood culture. From 171 dogs examinated, 39 (22.8\%) showed at least one clinical sign compatible with brucellosis, 58 (33.91\%) were AGID positive and $24(14.03 \%)$ were positive by blood culture. Gram negative bacterial cells with a biochemical pattern compatible with that of bacteria belonging to genus Brucella were isolated from blood specimens of 24 animals. According to Kappa index and McNemar test, the association between AGID and blood culture ( $k=0.360$ with $95 \%$ of confidence interval; $X^{2}=25.93, p=0.000$ ), between AGID and clinical test $\left(k=0.248\right.$ with $95 \%$ of confidence interval; $\left.X^{2}=6.11, p=0.013\right)$, and between blood culture and clinical examination ( $k=0.442$ with $95 \%$ of confidence interval; $X^{2}=6.76, p=0.009$ ) were not statistically significant. Qui-Square test indicated no association of sex and the results of clinical examination $\left(X^{2}=1.35\right.$ and $p=0.2447)$, $\operatorname{AGID}\left(X^{2}=1.58\right.$ and $\left.p=0.2086\right)$ or bacterial isolation $\left(X^{2}=1.48\right.$ and $\left.p=0.2230\right)$. Within 12 kennels, seven had at least one dog positive by blood culture and nine had at least one animal positive by AGID. The association of epidemiological data with direct and indirect methods of diagnosis is necessary to perform a definitive diagnosis of Brucella infection in dogs, as positive results by AGID can be consequence of non-specific reactions and must be confirmed by blood culture. Negative results by AGID must also be confirmed using direct methods of diagnosis or repeating the serologic test after 30 days, because of the low sensitivity of this test.
\end{abstract}

Key words: dogs, brucellosis, Brucella canis, diagnosis, isolation

\section{INTRODUCTION}

Canine brucellosis caused by Brucella canis is one of the major infectious causes of reproductive disorders in dogs. $(4,5,6,7,13,15,16,29,35)$. Enlargement of lymph nodes, uveitis, diskospondylitis, polyarthritis, glomerulonephritis, osteomyelitis and pyogranulomatous dermatitis are clinical signs other than reproductive failure often associated with brucellosis in dogs $(5,29)$. It is important to emphasize that some infected animals may be asymptomatic, being considered important sources of infection (16).

When brucellosis is introduced in a confined population, the infection spreads rapidly, leading to economic losses and risks for public health $(17,25,30,32,35)$.

In Brazil, epidemiological surveys of brucellosis in dogs from animal shelters of zoonosis control divisions or companion pets have been often assessed by using slide agglutination test (SAR) or agar gel immunediffusion test

*Corresponding author. Mailing address: Departamento de Medicina Veterinária Preventiva e Saúde Animal, Faculdade de Medicina Veterinária e Zootecnia, Universidade de São Paulo. Av. Prof. Dr. Orlando de Marques Paiva, 87. 05508-000, São Paulo, SP, Brasil. Tel.: (+5511) 3091 7704, Fax: (+5511) 3091 7928. E-mail: larakeid@yahoo.com.br 
(AGID) $(2,3,8,11,12,19,21,22,25,26,27,28,33,34)$. However, results of application of these methods for the diagnosis of brucellosis in commercial breeding kennels are rare.

Larsson et al. (19) tested 164 dogs from commercial breeding kennels in São Paulo, SP and observed $9.1 \%$ of positive animals by SAR and $2.4 \%$ by tube agglutination test (TAT). In four breeding kennels with history of abortion in metropolitan region of Botucatu, SP, Megid et al. (25) related seropositivity for Brucella infection in $12.0 \%$; $4.6 \% ; 31.0 \%$; and $41.4 \%$ by AGID test. Mólnar et al. (27) testing 236 dogs from animal shelters of zoonosis control divisions and companion animals from urban and rural area from Belém, PA, found $45.37 \% ; 38.56 \%$ and $46.14 \%$ of Brucella positive dogs, using AGID, complement fixation (CF) and ELISA respectively. The frequencies of positive dogs from commercial kennels were $40.32 \%$ by AGID, $25.80 \%$ by CF and $41.93 \%$ by ELISA.

The two rough species of Brucella, Brucella canis and Brucella ovis, share surface lipopolyssacharides (LPS) antigens, which can be used for the diagnosis of both canine and ovine brucellosis. Actually, the AGID test employing B. ovis LPS antigen has been extensively used to diagnose canine brucellosis. $(4,7,25,27,28,34)$.

However, the tests mentioned above often give false positive results because the surface antigens are also common to other bacteria species such as Pseudomonas aeruginosa, Staphylococcus spp. and Bordetella bronchiseptica $(4,6,7,16$, $24,29,36)$. Also, AGID and SAR are tests of low analytic sensitivity $(23,26)$, so they can fail to detect both early and chronic infections $(4,29)$.

As a consequence of the inaccuracy of serological tests, bacteriological methods should always be used to confirm the diagnosis of Brucella canis infection. Several samples can be employed for the direct detection of Brucella in dogs with blood samples being the best specimens to be chosen because: (i) Brucella infected dogs usually have a prolonged period of bacteremia; (ii) this kind of sample is rarely contaminated by other microorganisms because venal puncture is a procedure less prone to contamination; and (iii) blood culture allows the diagnosis of early infections, when sera antibody levels are not yet detectable by serological tests $(4,6,7,16,29)$. However, the success of Brucella isolation depends on the viability of the microorganism and also on the phase of the infection, so that negative results in these tests do not exclude the possibility of infection $(4,7,16)$.

In Brazil, only few reports of Brucella canis isolation from dogs have been published. In Belo Horizonte, MG, Godoy et al. (12) observed a B. canis positive blood culture from a female stray dog presenting vaginal discharge. Larsson and Costa (18) testing 27 dogs by TAT and blood culture found five animals positive by agglutination test and three positive by blood culture. Vargas et al. (35) isolated B. canis from tissues of placenta, aborted and neonatal fetuses from two female dogs from a kennel in Uruguaiana, RS. Gomes et al. (13) isolated successfully Brucella canis from genital organs from a dog presenting orchitis and epydidimitis,

The objective of the present work is to report the occurrence of Canine brucellosis in commercial breeding kennels localized in São Paulo State in which the animals were submitted to clinical examination and laboratorial diagnosis using AGID and blood culture.

\section{MATERIALS AND METHOD}

\section{Animals}

A Brucella infection study was conducted in a total of 50 male and 121 female dogs of several breeds from 12 commercial breeding kennels localized in São Paulo State, Brazil (Table 1). Sampling and obtention of clinical data occured between April 2000 and February 2002.

\section{Clinical examination}

The dogs were submitted to clinical examination and the owners were asked to answer a questionnaire to record the following clinical data: abortion, conception failure, vaginal discharge, whelping of dead puppies, neonatal death, orchitis, epididymitis, lymph nodes enlargement and uveitis. Canine brucellosis was suspected if an animal presented at least one of the clinical signs.

Table 1. Characteristics of the dogs from commercial breeding kennels in São Paulo State, according to the location of the kennel and sex of the animals.

\begin{tabular}{clccc}
\hline Kennel & \multicolumn{1}{c}{ Municipality } & $\begin{array}{c}\text { Number } \\
\text { of dogs }\end{array}$ & $\begin{array}{c}\text { Number } \\
\text { of males }\end{array}$ & $\begin{array}{c}\text { Number } \\
\text { of females }\end{array}$ \\
\hline 1 & Osasco/SP & 17 & 17 & 0 \\
2 & Campo Limpo Pta./SP & 22 & 1 & 21 \\
3 & São Paulo/SP & 18 & 5 & 13 \\
4 & Cotia/SP & 14 & 4 & 10 \\
5 & Campo Limpo Pta./SP & 4 & 1 & 3 \\
6 & Jaú/SP & 9 & 1 & 8 \\
7 & São Paulo/SP & 10 & 7 & 3 \\
8 & Mogi das Cruzes/SP & 15 & 2 & 13 \\
9 & Itu/SP & 37 & 8 & 29 \\
10 & São Bernardo do Campo/SP & 12 & 0 & 12 \\
11 & São Paulo/SP & 5 & 2 & 3 \\
12 & São Paulo/SP & 8 & 2 & 6 \\
\hline Total & & 171 & 50 & 121 \\
\hline
\end{tabular}




\section{Serologic diagnosis}

Sera were collected and tested by agar gel immunediffusion test (AGID), using Brucella ovis surface antigen, produced by Instituto Tecnológico do Paraná (Tecpar, PR, Brasil). The test were performed according to the laboratory recommendations, except for the substitution of agarose by $1 \%$ agar Noble (Difco, Detroit, MI, USA).

\section{Blood culture}

Blood samples were collected in sodium citrate anticoagulant. The culture were performed as described by Alton et al. (1). Briefly, $2 \mathrm{~mL}$ of blood with sodium citrate was inoculated in Castañeda medium and incubated at aerobic atmosphere, at $37^{\circ} \mathrm{C}$ for 30 days. After growth, colonies were cultured on Brucella agar plates and incubated at aerobic atmosphere at $37^{\circ} \mathrm{C}$ for five days for bacterial identification. The genus characterization were performed using Gram staining and identification of the biochemical profile: catalase, oxidase, citrate, indole, nitrate, motility, fermentation in TSI medium and urease. For identification of Brucella at species level, tests for $\mathrm{H}_{2} \mathrm{~S}$ production and growth of colonies in the presence of thionin and basic fucsin stains diluted 1:50,000 and 1:100,000 from $0.1 \%$ stock solution were performed.

\section{Statistical Analysis}

The agreement between AGID test and blood culture was determined by Kappa indexes. The association between the results of each laboratorial test with the clinical data was

Table 2. Positivity for Brucella according to the method of detection.

\begin{tabular}{ccccc}
\hline Kennel & $\begin{array}{c}\text { Number } \\
\text { ofdogs }\end{array}$ & $\begin{array}{c}\text { Clinically }_{\text {positive }^{I}} \\
\text { positive }\end{array}$ & $\begin{array}{c}\text { BGIood culture } \\
\text { positive }^{3}\end{array}$ \\
\hline 1 & 17 & $0(0 \%)$ & $7(41.17 \%)$ & $0(0 \%)$ \\
2 & 22 & $13(59.09 \%)$ & $16(72.72 \%)$ & $12(54.54 \%)$ \\
3 & 18 & $7(38.88 \%)$ & $14(77.77 \%)$ & $5(27.77 \%)$ \\
4 & 14 & $4(28.57 \%)$ & $1(7.14 \%)$ & $1(7.14 \%)$ \\
5 & 4 & $1(25.00 \%)$ & $2(50 \%)$ & $0(0 \%)$ \\
6 & 9 & $1(11.11 \%)$ & $6(66.66 \%)$ & $0(0 \%)$ \\
7 & 10 & $4(40.00 \%)$ & $4(40.00 \%)$ & $0(0 \%)$ \\
8 & 15 & $6(40.00 \%)$ & $6(40.00 \%)$ & $4(26.66 \%)$ \\
9 & 37 & $1(2.70 \%)$ & $0(0 \%)$ & $1(2.70 \%)$ \\
10 & 12 & $1(8.33 \%)$ & $0(0 \%)$ & $1(8.33 \%)$ \\
11 & 5 & $0(0 \%)$ & $2(40.00 \%)$ & $0(0 \%)$ \\
12 & 8 & $1(12.50 \%)$ & $0(0 \%)$ & $0(0 \%)$ \\
\hline Total & 171 & $39(22.80 \%)$ & $58(33.91 \%)$ & $24(14.03 \%)$ \\
\hline
\end{tabular}

1: Number and frequency of dogs with at least one clinical sign compatible with Brucella infection; 2: Number and frequency of dogs positive by agar gel immunediffusion test (AGID); 3: Number and frequency of dogs positive by blood culture. evaluated by McNemar test. Qui-square was used to evaluate the association of the results obtained with clinical or laboratory examinations with the sex of the animal. The statistical analises were performed using the Dag_Stat software (20).

\section{RESULTS}

Among the 171 examinated dogs, Brucella spp. were detected in blood specimens of 24 animals (14.62\%), 58 were (33.91\%) AGID positive and 39 (22.80\%) presented clinical signs of the disease. The frequencies of seropositive dogs observed in the commercial kennels ranged from $40 \%$ to $77.77 \%$ (Table 2). When blood cultures were performed, the frequencies of positive results ranged from $2.70 \%$ to $54.54 \%$ (Table 2).

The biochemical profile of the 24 isolates was: catalase positive, oxidase positive, nitrate reduction positive, $\mathrm{H}_{2} \mathrm{~S}$ production negative, fermentation in TSI media negative, indole negative, citrate negative, motility negative, urease positive. The growth pattern of the isolates in the presence of thionin and basic fucsin is presented in Table 4 .

The concordance between AGID and blood culture using Kappa index, with 95\% confidence interval indicated a fair agreement $(k=0.360)$. The association between AGID and blood culture results were not statistically significant $\left(\mathrm{X}^{2}=25.93, p=\right.$ 0.000 ) as determined by $\mathrm{McNemar}$ test.

The association between the results of the laboratorial tests and clinical data were analyzed by McNemar test and Kappa index. The McNemar test indicated no concordance between the observation of clinical signs and the AGID results $\left(\mathrm{X}^{2}=6.11\right.$ and $\left.p=0.013\right)$, nor between the presence of clinical signs and blood culture results $\left(\mathrm{X}^{2}=6.76\right.$ and $p=0.009)$. Kappa index indicated moderated agreement between clinical evaluation and blood culture $(k=0.442,95 \%$ confidence interval) and fair agreement between clinical evaluation and AGID ( $k=0.248,95 \%$ confidence interval).

Using Qui-Square test, the sex of the animal could be associated neither with the results obtained with clinical examination nor with results of laboratory tests. The $p$ values and $\mathrm{X}^{2}$ of the statistical test for the associations of sex of the animal with results of clinical examination, AGID and blood culture were respectively: $p=0.2447, \mathrm{X}^{2}=1.35$ for clinical examination, $p=0.2086$ and $\mathrm{X}^{2}=1.58$ for AGID, and $p=0.2230$ and $\mathrm{X}^{2}=1.48$ for blood culture.

\section{DISCUSSION}

With regard to the resistance to thionin and basic fucsin, 18 from the 24 isolates had a biochemical pattern similar to $B$. canis of Canadian or Mexican origin, as described by Forbes and Pantekoek (10) 
and by Gomes et al. (13). The remaining isolates had a biochemical pattern compatible with Brucella canis RM6/66 reference strain (1), which was also observed by Larsson and Costa (18) and Godoy et al. (12) (Table 4).

Although Brucella species have some degree of host specificity and most of the investigated kennels presented positive dogs by AGID for rough species, the likelihood of other species of Brucella being responsible for the infections should not be discarded, specially in those populations where positive AGID results were not observed $(9,13)$. Moreover, thionin and fucsin resistance should not be taken as a gold standard to classify Brucella at the species level, as some strains of $B$. suis and B. abortus could present growth patterns similar to $B$. canis (1).

In three from 12 kennels, there was at least one animal presenting clinical signs of brucellosis, one animal AGID positive and none blood culture positive (Table 3). Because of the low accuracy of the serological tests, the absence of microbiological isolation in these kennels leads to two possible conclusions: either the occurrence of non-specific reactions of AGID or the presence of chronically infected but abacteremic dogs, that shelter the bacteria in other organs $(4,6,16,24,29)$. In kennels having at least one AGID positive and no blood culture negative dog, Brucella infection can not be confirmed, with or without clinical signs (Table 3).

In two from 12 kennels, there was at least one AGID positive animal, but neither Brucella spp. could be isolated nor clinical signs compatible with brucellosis could be assigned (Table 3 ). In this case, the results can also be a consequence of either animals presenting chronic and abacteremic infection or nonspecific AGID results $(4,7,16,29)$.

Four kennels presented dogs showing clinical signs of brucellosis and with positive AGID and blood culture (Table 3). Even though the isolation of microorganism from at least one animal from a suspected population of dogs confirms Brucella infection, it does not mean that all AGID positive but blood culture negative dogs were really infected mainly because of the low specificity of the serological test $(4,7,16,29,36)$. In a situation like that, it is imperative to considerate the herd management, as the kennels in which the dogs are kept in collective pens or whose dogs have frequent external mating, the risk of dissemination of the infection is higher when compared with populations in which the animals are kept in individual pens and the exchange of dogs is not practiced frequently $(6,25)$.

In all kennels where Brucella spp. was isolated from at least one $\operatorname{dog}(6 / 12)$, clinical signs of the infection were observed at
Table 4. Growth pattern of 24 Brucella spp. isolates in medium containing thionin and basic fucsin.

\begin{tabular}{ccccc}
\hline $\begin{array}{c}\text { Number of } \\
\text { Brucella } \\
\text { isolates }\end{array}$ & Thionin & \multicolumn{2}{c}{ Basic Fucsin } \\
\hline & $1: 50,000$ & $1: 100,000$ & $1: 50,000$ & $1: 100,000$ \\
\cline { 2 - 5 } 18 & positive & positive & positive & positive \\
6 & positive & positive & negative & negative \\
\hline
\end{tabular}

least once, irrespectively the results of AGID (Table 3). However statistical correlation between results of clinical examination and blood culture revealed no association (McNemar test) and a moderate agreement (Kappa index). This is indicative that the presence of clinical signs is not enough to evidence Brucella infection at a herd level.

From the six kennels in which Brucella were isolated, two have no AGID positive animals. This information suggests that the AGID test lacks sensitivity and the AGID negative/blood culture positive dogs were possibly in early infection, when sera antibodies did not achieve detectable level $(4,7,16)$.

Although AGID is considered a good screening test to be applied for diagnosis of canine brucellosis at the population level, the results presented here indicate that negative results 
obtained with AGID test must be carefully interpreted, specially in kennels where clinical signs of brucellosis are observed. $(7,29,31)$. From the results, it may be inferred that AGID has not a satisfactory performance to be chosen as a screening test for the detection of Brucella infection in dogs.

As a proposal to control Brucella infection in commercial kennels, we suggest careful analysis of the results obtained with serodiagnosis, bacteriological assays and clinical examination of the dogs, so that the presence of a single blood culture positive dog confirms the infection in a suspected population (16). In a case such like that, the remaining dogs (AGID positive/blood culture negative) should also be considered infected and removed from the kennel, with the aim of minimizing the risk of transmission and reducing the infection prevalence in the population. However, it should be in mind that a considerable number of non infected animals can be eliminated from the population.

Negative results obtained by AGID test should also be confirmed, because of the low sensitivity $(23,26)$ and consequently the low accuracy to detect early infections $(4,7,16)$. Again, it is stressed the importance of the concurrent use of direct and indirect methods for the diagnosis of Brucella infections. Nevertheless, we emphasize that the absence of positive dogs by bacterial isolation in kennels where serologically positive dogs are observed do not mean that Brucella infection is absent. In a situation like that, serological and bacteriological tests must be repeated each 30 days for infection surveillance.

When brucellosis is detected in a kennel, quarantine and monthly serological and bacteriological monitoring for four to five months, associated with rigorous disinfection are essential to control the infection (16).

Considering the difficulties mentioned above, it is clear that the association of direct and indirect laboratorial tests with clinical and epidemiological data is essential to perform a definitive diagnosis of brucellosis.

\section{ACKNOWLEDGMENTS}

This work was supported by FAPESP (grant n ${ }^{\circ}$ 99/02662-1).

\section{RESUMO}

\section{Detecção de Brucella em cães provenientes de canis comerciais do estado de São Paulo, Brasil}

Cães provenientes de 12 canis comerciais do estado de São Paulo foram submetidos à investigação clínica e a provas laboratoriais para o diagnóstico de infecção por Brucella spp. A colheita de amostras foi realizada entre os meses de abril de 2000 e fevereiro de 2002 e os exames laboratoriais empregados foram a imunodifusão em gel de ágar (IDGA) e a hemocultura.
De 171 cães examinados, 39 (22,80 \%) apresentaram pelo menos um sinal clínico compatível com brucelose, 58 (33,91\%) foram positivos pela IDGA e $24(14,03 \%)$ pela hemocultura. Bactérias Gram negativas com perfil bioquímico compatível com o gênero Brucella foram isoladas das 24 amostras de sangue positivas pelo isolamento bacteriano. De acordo com o coeficiente Kappa e o teste de McNemar, não foi observada concordância entre os resultados obtidos na hemocultura e IDGA $(k=0,360$ com intervalo de confiança de 95\%; $\left.\mathrm{X}^{2}=25,93, p=0,000\right)$, entre resultados da IDGA e do exame clínico $(k=0,248$ com intervalo de confiança de $\left.95 \% ; \mathrm{X}^{2}=6,11, p=0,013\right)$ e entre os resultados da hemocultura e do exame clínico $(k=0,442$ com intervalo de confiança de 95\%; $\left.\mathrm{X}^{2}=6,76, p=0,009\right)$. A associação dos resultados obtidos pelos exames clínicos e laboratoriais com o sexo dos animais não foi estatisticamente significante (QuiQuadrado), sendo observado $\mathrm{X}^{2}=1,35$ e $p=0,2447$ para o exame clínico, $\mathrm{X}^{2}=1,58$ e $p=0,2086$ para IDGA e $\mathrm{X}^{2}=1,48$ e $p=0,2230$ para hemocultura. Dos 12 canis examinados, sete apresentaram pelo menos um animal positivo pela hemocultura e nove pelo menos um animal positivo pela imunodifusão. A associação de dados epidemiológicos com testes laboratoriais diretos e indiretos deve ser enfatizada para o diagnóstico definitivo da brucelose canina. Resultados positivos pela imunodifusão em gel de ágar podem ser conseqüência de reações inespecíficas e devem ser confirmados pela hemocultura. Os resultados negativos obtidos pela imunodifusão também devem ser confirmados utilizandose métodos diretos de diagnósticos ou repetindo-se o teste sorológico com 30 dias de intervalo, devido à baixa sensibilidade desse teste diagnóstico.

Palavras-chave: cães, brucelose, Brucella canis, diagnóstico, isolamento

\section{REFERENCES}

1. Alton, G.G.; Jones, L.M.; Pietz, D.E. Tecnicas de laboratorio en la brucelosis. Ginebra: Organizacion Mundial de la Salud, 1976. $109 \mathrm{p}$.

2. Alves, F.A.L.; Alves, C.J.; Azevedo, S.S.; Andrade, J.S.L.; Santos, F.A.S. Prevalência de anticorpos anti-Brucella canis em cães na cidade de Patos-PB. Congresso Pernambucano de Medicina Veterinária, 4 1999, Recife, PE. Anais Sociedade Pernambucana de Medicina Veterinária, p.259-260.

3. Azevedo, S.S. Brucelose por Brucella canis em cães do município de Santana de Parnaíba - SP, Brasil. Inquérito sorológico, fatores de risco e comparação de testes diagnósticos. São Paulo, 2002. 100p. [Dissertação (mestrado) - Faculdade de Medicina Veterinária e Zootecnia/USP].

4. Carmichael, L.E. Canine brucellosis: an annoted review with selected cautionary comments. Theriogenology, 6(2-3): 105-116, 1976.

5. Carmichael, L.E.; Greene, C.E. Canine brucellosis. In: Greene, C.E. (Ed). Infectious diseases of the dog and cat. Philadelphia: W.B. Saunders, 1998, p.573-584.

6. Carmichael, L.E.; Kenney, R.M. Canine brucellosis: the clinical disease, pathogenesis and immune response. J. Am. Vet. Med. Assoc., 156(12): 1726-1734, 1970. 
7. Carmichel, L.E.; Shin, S.J. Canine brucellosis: a diagnostician's dilemma. Sem. Vet. Med. Surg. (Small Animal), 11(3): 161-165, 1996.

8. Côrtes, V.A.; Oliveira, M.C.G.; Ito, F.H.; Vasconcellos, S.A. Reações sorológicas para Brucella canis em cães errantes capturados na proximidade dos parques públicos, reservas florestais e em áreas periféricas do município de São Paulo - Brasil. Rev. Fac. Med. Vet. Zoot. Univ. S. Paulo, 25(1): 101-107, 1988.

9. Forbes, L.B. Brucella abortus infection in 14 farm dogs. J. Am. Vet. Med. Assoc., 196(6): 911-916, 1990.

10. Forbes, L.B.; Pantekoek, J.F. Brucella canis isolates from Canadian dogs. Can. Vet. J., 29: 149-152, 1988.

11. Germano, P.M.L.; Vasconcellos, S.A.; Ishizuka, M.M.; Passos, E.C.; Erbolato, E.B. Prevalência de infecção por Brucella canis em cães da cidade de Campinas - SP, Brasil. Rev. Fac. Med. Vet. Zoot. Univ. S. Paulo, 24(1): 27-34, 1987.

12. Godoy, A.M.; Peres, J.N.; Barg, L. Isolamento de Brucella canis em Minas Gerais, Brasil. Arq. Esc. Vet. UFMG, 29(1): 35-42, 1977.

13. Gomes, M.J.P.; Driemeier, D.; Soares, H.C.; Bastos, C.D.; Canto, S.P.; Brum, M.; Rossi, A.C.; Coberllini, L.G. Brucella canis: isolamento em um cão com epididimite e orquite - relato de um caso. Clin. Vet., 18: 17-20, 1999.

14. Gomes, O.G.; Portugal, M.A.S.C.; Giorgi, W.; França, E.N. Brucella suis Biotype I infection in a dog. Arq. Inst. Biol., 39(4): 251-255, 1972.

15. Hubbert, N.L.; Bech-Nielsen, S.; Barta, O. Canine brucellosis: comparison of clinical manifestations with serologic test results. $J$. Am. Vet. Med. Assoc., 177(2): 168-171, 1980.

16. Johnson, C.A; Walker, R.D. Clinical signs and diagnosis of Brucella canis infection. Comp. Cont. Edu., 14(6): 763-772, 1992.

17. Jones, R.L.; Emerson, J.K. Canine brucellosis in a commercial breeding kennel. J. Am. Vet. Med. Assoc., 184(7): 834-835, 1984.

18. Larsson, M.H.M.A.; Costa, E.O. Isolation of Brucella canis. Int. J. Zoo., 7: 125-130, 1980.

19. Larsson, M.H.M.A.; Larsson, C.E.; Mirandola, R.M.S.; Yasuda, P.H.; Grutolla, G. Canine brucellosis in São Paulo: serologic survey of kennel and stray dogs. Int. J. Zoo., 8: 85-90, 1981.

20. Mackinnon, A. A spreadsheet for the calculation of comprehensive statistics for the assessment of diagnostic tests and inter-rater agreement. Comp. Biol. Med., 30(3): 127-134, 2000.

21. Magalhães Neto, A.; Da Cruz, F.W.; Santos, A.F.; Gil-Turnes, C.; Aleixo, J.A.G.; Martins, L.F.S.; Brod, C.S.; Gurvitz, R. Prevalência de humanos e caninos reatores à Brucella rugosa no município de Pelotas, RS. XI Congresso Estadual de Medicina Veterinária, 3-7, 1992, Gramado. Anais, p.92.
22. Maia, G.R.; Rossi, C.R.S.; Abbadia, F.; Vieira, D.K; Moraes, I.A Prevalência da brucelose canina nas cidades do rio de janeiro e Niterói. Rev. Bras. Reprod. Anim., 23(3): 425-427, 1999.

23. Margini, R.A. Inmunologia e inmunoquímica: fundamentos. 5.ed. Argentina: Editorial Médica Panamericana, 1996, p.176-200.

24. Mateu-de-Antonio, E.M.; Martín, M.; Casal, J. Comparison of serologic testes used in canine brucellosis diagnosis. J. Vet. Invest., 6: 257-259, 1994

25. Megid, J.; Brito, A.F.; Moraes, C.C.G.; Fava, N.; Agottani, J. Epidemiological assessment of canine brucellosis. Arq. Bras. Med. Vet. Zoo., 51(5): 439-440, 1999.

26. Melo, S.M.B.; Nascimento, R.M.; Aguiar, P.H.P.; Freire, S.M.F. Avaliação sorológica em gel de agarose para diagnóstico de Brucella canis em cães no distrito de Monte Gordo-Camaçari-Bahia. Arq. Esc. Med. Vet. UFB, 19(1): 119-127, 1997.

27. Mólnar, L.; Mólnar, E.; Carvalho, M. Capacidade de algumas provas sorológicas no diagnóstico de brucelose canina. A Hora Veterinária, 121: 45-49, 2001.

28. Moraes, C.C.G.; Megid, J.; Souza, L.C.; Crocci, A.J. Prevalência da brucelose canina na microrregião da Serra de Botucatu, São Paulo, Brasil. Arq. Inst. Biol. S. Paulo, 69(2): 7-10, 2002.

29. Nielsen, K.; Duncan, J.R. Animal Brucellosis. Boca Raton: CRC Press, 1990. 453p.

30. Pickerill, P.A.; Carmichael, L.E. Canine brucellosis: control programs in commercial kennels and effect on reproduction. J. Am. Vet. Med. Assoc., 160: 1607-1615, 1972.

31. Robles, C.A. Evaluacion de una tecnica de doble difusion en gel de agar para el diagnostico de la infeccion por Brucella ovis en carneros. Vet. Arg., 15(142): 119-124, 1998.

32. Roxo, E.; Pinheiro, S.R.; Brandão, M.M.; Aguiar, J.A.C.; Gouvêa, G.;Piorum, M.L.; Lima, M.A.B. Brucelose canina: relato de uma possível transmissão de Brucella canis ao homem a partir de uma cadela da raça Dobermann. Arq. Inst. Biol., 55(19): 11-13, 1990.

33. Sandoval, L.A.; Ribeiro, L.O.C.; Amaral, L.B.S.; Feitosa, M.H.; Bazan, J.M. Incidência da brucelose canina na cidade de São Paulo. $O$ Biológico, 42(32): 128-132, 1976.

34. Souza, L.A.; Viana, R.C.A.; Michalick, M.S.M.; Reis, J.K.P.; Lage, A.P. Prevalência de infecção por Brucella canis em Belo Horizonte - MG. Rev. Bras. Med. Vet., 24(3): 127-131, 2002.

35. Vargas, A.C.; Lazzari, A.; Dutra, V.; Poester, F. Brucelose canina: relato de caso. Ciência Rural, 26(2): 305-308, 1996.

36. Zoha, S.T.; Carmichael, L.E. Serological responses of dogs to cell wall and internal antigens of Brucella canis (B. canis). Vet. Microbiol., 7: $35-50,1982$. 